\title{
The Drivers of Entrepreneurial Intention: The Role of Social Capital and Overconfidence
}

\author{
Lin-Ju Cheng \\ St. John's University \\ E-Mail: clrvicky@mail.sju.edu.tw \\ Chun-Chieh Liao \\ Chinese Culture University \\ E-Mail: 1jj4@faculty.pccu.edu.tw
}

\begin{abstract}
This study integrated the theory of social capital and cognitive bias to investigate the formation of entrepreneurial intentions. Among many kinds of biases, we took overconfidence biases that have been studied widely and relevant to entrepreneurship into consideration. Moreover, this study proposed that social capital of entrepreneurs matter for overconfidence biases, and investigated whether the relationship between social capital and entrepreneurial intention is mediated by overconfidence. Furthermore, following Seibert et al. (2001), this study conceptualized social capital into two components: (1) access to information and resources, and (2) career sponsorship. Using university students in Taiwan as our research sample, we collected 346 samples, and adopted the SEM technique to test the hypotheses. The empirical results indicated that social capital in terms of information and resource accessibility can encourage young people to consider entrepreneurship as a career, while social capital in terms of career sponsorship can inspire entrepreneurial intention mediated only by overconfidence.
\end{abstract}

Keywords: Social Capital, Cognitive Bias, Overconfidence, Entrepreneurial Intention 


\section{INTRODUCTION}

Based on the drastic changes in the labour market, government and policy-makers worldwide are looking for ways to drive innovation and create jobs (Van Praag and Versloot, 2007). Today's unprecedented entrepreneurial boom is creating career opportunities for young people. A rising number of creative young people is eager to learn entrepreneurship (York and Venkataraman, 2010).

Due to the call for more entrepreneurship and more entrepreneurial activities (York and Venkataraman, 2010), knowing the intention and willingness of people in the labour market is important. It would help us to investigate the way in which entrepreneurial ventures are created. Drawing from trait approach, early studies tried to explore how many psychological traits differentiate entrepreneurs from non-entrepreneurs (Das and Teng, 1997; Hatten and Coulter, 1997; Shaver and Scott, 1991). Afterwards, researchers began to investigate how entrepreneurs think (Wadeson, 2008). Using cognitive approaches allow us to distinguish the beliefs, values, cognitive styles and mental processes of entrepreneurs from those of non-entrepreneurs (Sa'nchez, Carballo, and Gutiérrez, 2011).

In a rapidly changing environment, high uncertainty makes decision-making process more complex. It is difficult to act as a rational decision maker. Kannadhasan and Nandagopal (2010) suggest that cognitive biases play an important role in decision making. This study has extended a cognitive theory in the context of new venture formation by capturing the entrepreneurs' perceptions of their overconfidence and decision to start a new venture (Keh, Foo, and Lim, 2002; Zacharakis and Shepherd, 2001).

Borrowing from the theory of cognitive bias, this study observed how cognitive biases affect the decision to create a new venture (Laibson and Zeckhauser, 1998). Among many kinds of cognitive biases, this study considered overconfidence -- 'a failure to recognize the limits of our knowledge' (Baron and Markman, 1999) -- that has been studied widely and that is relevant to entrepreneurship (Krueger, 2005). The purpose of this study was to examine how overconfidence as a cognitive bias affects entrepreneurs' decision making.

The literature on entrepreneurship has examined the relationships between biases and a range of constructs including the decision to start a venture (Franke, Von Hippel, and Schreier, 2006; Keh et al., 2002; Simon, Houghton and Aquino, 2000). Another purpose of this study was to study what factors affect overconfidence biases.

Drawing upon the theory of social capital, the researchers propose that social environment interacting with individuals and organizations, drives the opportunity for discovery, evaluation, and exploitation (Corbett, 2007; De Carolis and Saparito, 
2006). Social capital refers to the value embedded in the social relationships of individuals or collectives (Adler and Kwon, 2002; Payne, Moore, Griffis, and Autry, 2011). Social capital was a foundational theoretical perspective (Murphy, 2011) that has the potential to recognize entrepreneurship (Baron and Tang, 2009; Liao and Welsch, 2005; Ireland, Hitt, and Sirmon, 2003). De Carolis and Saparito (2006) proposed that entrepreneurs' rich social capital could deepen their cognitive biases (representativeness bias). De Carolis, Yang, Deeds, and Nelling (2009) empirically confirmed the fact that an entrepreneur's social capital would enhance shared attitudes and mental models through social ties, which in turn would increase cognitive bias (illusion of control). These two papers ignore the overconfidence bias and the mediating role of social capital on entrepreneurial intention. This study aimed to fill the gap.

In terms of the operationalization of social capital, this study argues that entrepreneurship related to social capital, rather than general social capital is more powerful in explaining entrepreneurial intention. Following Seibert, Kraimer, and Liden (2001), social capital includes accessibility of information or resources and career sponsorship.

According to these statements, this study was aimed to integrate social capital theory and the theory of entrepreneurial cognition, and to investigate the relationship among social capital, overconfidence and entrepreneurial intention.

\section{LITERATURE REVIEW}

\section{Social Capital}

Social capital does not have a clear, undisputed meaning (Dolfsma and Dannreuther, 2003; Foley and Edwards, 1997), it indicated the value embedded in the social relationships of individuals and collectives (Adler and Kwon, 2002; Payne et al., 2011). Nahapiet and Ghoshal (1998, p. 243) defined that social capital as "the sum of actual and potential resources embedded within, available through, and derived from the network of relationships possessed by individuals or social units." The relationship between social capital and entrepreneurial intention have been tested before (De Carolis and Saparito, 2006; De Carolis et al., 2009; Liñán and Santos, 2007; Schlaegel and Koenig, 2014). Prior studies have pointed out that social capital is a key factor for entrepreneurial opportunities (Shane and Venkataraman, 2000). It has an encouraging effect on entrepreneurial careers (Liao and Welsch, 2005). Acquiring and managing social capital plays a key role in entrepreneurial success, which can apply to newly created ventures (Baron and Tang, 2009). In other words, entrepreneurs' social capital e can imbue them with a sense of security and heighten 
their entrepreneurial intention. But such studies have considered only the direct relation between social capital and entrepreneurial intentions, ignoring the possible indirect effects through mediating variables (e.g., cognitive bias).

Borrowing from the entrepreneurship-related definition of social capital of Seibert et al. (2001), this study conceptualized social capital into two components: (1) access to information and resources, and (2) career sponsorship. The benefits of social capital include greater and most timely access to information, greater access to financial or material resource, and greater visibility, legitimacy, or sponsorship within a social system. As such, it can affect people's decision to create new ventures.

\section{Overconfidence}

It can be a challenge to use all available information to be a rational decision maker. Cognitive biases have a significant role in decision making (Kannadhasan and Nandagopal, 2010). These biases include overconfidence, illusions of control, and representativeness (Busenitz and Barney, 1997; De Carolis and Saparito, 2006; De Carolis et al., 2009). This study chooses overconfidence as main variable. Although overconfidence has no common definition among scholars, it became one of important variables in predicting individuals' propensity for entrepreneurial activity. Overconfidence bias refers to overestimation of one's actual skill or chance of success either in absolute terms or relative to others and related to one's ability to make accurate predictions or to know the truth (Hayward, O'Brien, Hofmeyr, and Kerley, 2006; Moore and Healy, 2008; Moore and Kim, 2003; Townsend, Busenitz, and Arthurs, 2010). Overconfident individuals attach higher probabilities to outcomes than are warranted by what they know (Zacharakis and Shepherd, 2001), thus may affect the decision of new venture formation.

\section{Entrepreneurial Intention}

According to Tubbs and Ekeberg (1991), intention might be viewed as cognitive representation of the objective of an individual and the plan designed to complete the objective. Bird (1988) defined intention as a state of mind directing a person's attention toward a specific object. As it has been seen, both views have involved an objective as the major component of an intention. Typically, entrepreneurial objectives have strived for starting a new venture or creating new value (Bird, 1988; Shane and Venkataraman, 2000). It was suggested that impact of intention is especially crucial at the moment of inception of the entrepreneurial process. In addition, entrepreneurial intention can have the degree of influence on actions of already existing businesses. Therefore, this study defines that entrepreneurial intention as a state of mind directing 
a person's attention toward a specific object, such as a new venture (Bird, 1988; Shane and Venkataraman, 2000).

\section{METHODOLOGY}

\section{Research Framework}

Our framework is organized into three constructs of concepts, social capital, overconfidence and entrepreneurial intention. The three sets of concepts and the relationships between them form a framework that suggests both factors can influence one's entrepreneurial career choice decision, and social capital can indirectly affect entrepreneurial intention via the mediation of overconfidence. (Figure 1)

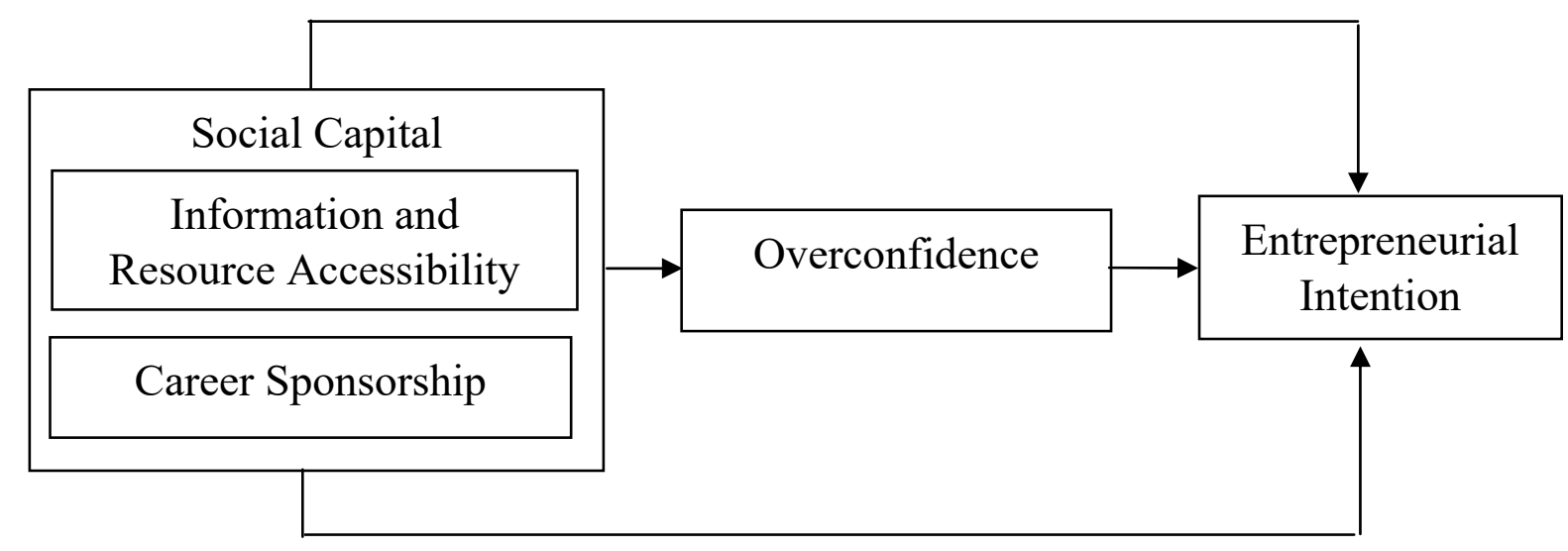

Figure 1 Research Framework

\section{Research Hypotheses}

Social capital in terms of information and resource accessibility could provide expertise or emotional support (Brüderl, and Preisendörfer, 1998), tapped into market information, and accessed other talents (Birley, 1986; Zimmerman and Zeitz, 2002). Information and resource also accelerated the timing, relevance, and quality of information (Adler and Kwon, 2002; Burt, 1995). Baron (2008) suggested that social networks might play a key role for entrepreneurs in identifying and recognizing opportunities for innovative ventures. These kinds of social capital helped entrepreneurs in opportunity identification (Bhagvatula, Elfring, Van Tilburg, and Van De Bunt, 2010), establishment of business (Birley, 1986) as well as in firm performance (Stam, Arzlanian, and Elfring, 2014).

Regarding social capital in terms of career sponsorship, like mentors, the positive effects of career sponsorship, has been demonstrated in the literature (Chao, 1997). Sullivan (2000) argued that mentors add value in interventions that make a difference 
in the long-term success of these businesses. Mentors often provide entrepreneurs the support they need when it matters most. Individuals relied on relationships to provide emotional reassurance and critical aid (Fisher, 1985). Mentoring has been shown to be a crucial source of social support. Accordingly, the following hypotheses are formulated:

$\mathrm{H}_{1 \mathrm{a}}$ : Social capital in terms of information and resource accessibility has a positiveeffect on entrepreneurial intention.

$\mathrm{H}_{1 \mathrm{~b}}$ : Social capital in terms of career sponsorship has a positive effect on entrepreneurial intention.

Townsend, Busenitz, and Arthurs (2010) argued that entrepreneurial careers were frequently pursued by people who tend to to anticipate unreasonably high outcomes and to overestimate their abilities. Trevelyan (2008) noted that ability to recognize and exploit entrepreneurial opportunities were higher among overconfident entrepreneurs, since they viewed this activity as something that promises a positive outcome. It has been suggested that overconfidence appears to be what drives people to become entrepreneurs (Koellinger, Minniti, and Schade, 2007).

The decision to choose the entrepreneurial path and launch a new venture is driven by cognitive process based on the entrepreneur's state of mind. That could be overconfidence, unreasonably high expectations, and exaggerated evaluations of opportunity significance (Hayward et al., 2006; Koellinger et al., 2007, Trevelyan, 2008). Buttar (2015) found that entrepreneurs' overconfidence increased theoir entrepreneurial intention. Hayward, Forster, Sarasvathy, and Fredrickson (2010) pointed out that overconfidence may stimulate positive emotions, increase entrepreneurs' resilience to obstacles, and propel entrepreneurs to invest more in subsequent rounds. Accordingly, the following hypothesis is formulated:

$\mathrm{H}_{2}$ : An entrepreneur's overconfidence has a positive effect on his entrepreneurial intention.

The extent of a person's social capital in terms of resource accessibility may affect his cognitive mechanisms. According to Baron and Ensley (2006), experienced entrepreneurs might form more detailed patterns about what constitute an entrepreneurial opportunity. This detailed pattern requires more information input, while the patterns used by novice entrepreneurs, which are rougher and use less information input, may trigger overconfidence. In addition, with more resource accessibility, by communicating intensively with the entrepreneurs in one's social network, an individual may develop a strong affinity for entrepreneurship. Baron (2008) argued that the positive effect on entrepreneurship might cause overconfidence. 
If an individual felt strongly positive about the entrepreneurial experiences in his or her social networks, this strong emotion may affect his memory: individuals could only remember information that was consistent with this positive effect (Baron, 2008), thus cause overconfidence.

In their work on capital in terms of career sponsorship, Carr and Sequeira (2007) found that potential entrepreneurs often received emotional support from their social ties (Inkpen and Tsang, 2005). Network support may boost overconfidence in potential entrepreneurs. Accordingly, the following hypotheses are formulated:

$\mathrm{H}_{3 \mathrm{a}}$ : Social capital in terms of information and resource accessibility has a positive effect on an entrepreneur's overconfidence.

$\mathrm{H}_{3 \mathrm{~b}}$ : Social capital in terms of career sponsorship has a positive effect on an entrepreneur's overconfidence.

An entrepreneurial decision is bounded by a person's external social factors and internal cognitive capabilities (Mitchell, Busenitz, Bird, Marie Gaglio, McMullen, Morse, and Smith, 2007, Gigerenzer and Gaissmaier, 2011). This study proposes that overconfidence biases may mediate the relationship between an individual's social network properties and his/her entrepreneurial intention.

If an entrepreneur could gather rich information from his/her social network, it may cause a wide range of cognitive biases, including overconfidence. By communicating intensively with the resources in one's social network, an entrepreneur may think that what he/she likes is what is good, leading to overconfidence biases (Baron, 2008).

Carr and Sequeira (2007) also found that potential entrepreneurs often received career sponsorship from their social ties. Sequeira, Mueller, and McGee (2007) argued that such benefits include emotion, participation, and helpfulness. The emotional support indicates that the person would feel good about the decision to launch a start-up. Participation support means that specific social ties would join him/her in the entrepreneurial process. Helpfulness support suggests that resources would be offered in the new venture. People with such career sponsorship are more likely to overestimate the knowledge, competencies and resources available for the new start-up. Accordingly, the following hypotheses are formulated:

$\mathrm{H}_{4 \mathrm{a}}$ : Social capital in terms of information and resource accessibility has a positive effect on entrepreneurial intention of entrepreneurs, which is mediated by an entrepreneur's overconfidence. 
$\mathrm{H}_{4 \mathrm{~b}}$ : Social capital in terms of career sponsorship has a positive effect on entrepreneurial intention of entrepreneurs, which is mediated by an entrepreneur's overconfidence.

\section{Definition and Measurement Items}

All of the questionnaire items were adapted from existing instruments. Social capital consisted of ten items originally developed by Seibert et al. (2001). Overconfidence, which consisted of five items, defined a person's tendency to exaggerate their abilities, skills and information when starting a new business (Hayward et al., 2006; Townsend et al., 2010) (McGee, Peterson, Mueller, and Sequeira, 2009; Tominc \& Rebernik, 2007). Entrepreneurial intention was a state of mind directing a person's attention toward a specific object, such as a new venture (Bird, 1988; Shane and Venkataraman, 2000), and was measured by six items adapted from Carr and Sequeira (2007), Krueger, Reilly, and Carsrud (2000). Aside from the demographic characteristics of the students participating in this study (gender, age, and work experience), all items were measured by a five-point Likert rating scale which ranged from 1 for strongly disagree to 5 for strongly agree.

\section{Sampling and Data Collection}

The purpose of this study was to examine the relationship among social capital, overconfidence and entrepreneurial intention. The samples were university students who enrolled in each of the three entrepreneurship courses at a Taiwanese university. There were 370 samples yielding 346 useful questionnaires for an effective response rate of 93.5 percent.

This study used descriptive statistics to analyze the results from the questionnaire. Reliability and validity were tested. Structural Equation Modeling (SEM) was used to test the hypotheses.

Among the respondents, 48.4 percent were male, and 70 percent were between the ages of 21 and 30. Work experience of these university students is less than 1 year, account for 43.5 percent.

\section{RESULTS}

\section{Reliability and Validity}

Except overconfidence (OC), other cronbach's $\alpha$ were greater than 0.8 , showing high reliability. In this study, all measurement items' factor loadings were greater than the suggest threshold value of 0.5 (Hair, Black, Babin, Anderson, and Tatham, 2006). Composite reliability (CR) was greater than the suggest threshold value of 0.7 (Chin, 
1998). This study demonstrated adequate internal consistency.

This study used confirmatory factor analysis (CFA) to measure convergent validity. The results showed an average greater than 0.4 ; the items of this study were convergent. Fornell and Larcker (1981) proposed average variance extracted (AVE) to measure discriminant validity. AVE square root should be greater than the correlation coefficients for each pair of constructs. In this study, all AVE square roots were greater than the correlation coefficients for each pair of constructs, demonstrating discriminant validity. Table 1 and Table 2 show the results of reliability, validity analysis, AVE square root and correlation matrix.

Table 1 Reliability and Validity Analysis

\begin{tabular}{|c|c|c|c|c|c|}
\hline Constructs & Items & Factor Loading & Cronbach's $\alpha$ & $\mathrm{CR}$ & AVE \\
\hline \multirow{5}{*}{$\begin{array}{l}\text { Information and Resource } \\
\text { Accessibility(SCR) }\end{array}$} & SCR1 & 0.696 & \multirow{5}{*}{0.817} & \multirow{5}{*}{0.802} & \multirow{5}{*}{0.477} \\
\hline & SCR2 & 0.729 & & & \\
\hline & SCR3 & 0.740 & & & \\
\hline & SCR4 & 0.686 & & & \\
\hline & SCR5 & 0.594 & & & \\
\hline \multirow{5}{*}{ Career Sponsorship(SCS) } & SCS1 & 0.623 & \multirow{5}{*}{0.805} & \multirow{5}{*}{0.811} & \multirow{5}{*}{0.466} \\
\hline & SCS2 & 0.722 & & & \\
\hline & $\mathrm{SCS} 3$ & 0.743 & & & \\
\hline & SCS4 & 0.748 & & & \\
\hline & SCS5 & 0.554 & & & \\
\hline \multirow{5}{*}{ Overconfidence(OC) } & OC1 & 0.610 & \multirow{5}{*}{0.798} & \multirow{5}{*}{0.804} & \multirow{5}{*}{0.452} \\
\hline & OC2 & 0.727 & & & \\
\hline & OC3 & 0.641 & & & \\
\hline & OC4 & 0.734 & & & \\
\hline & OC5 & 0.639 & & & \\
\hline \multirow{6}{*}{$\begin{array}{l}\text { Entrepreneurial } \\
\text { intentions(EI) }\end{array}$} & EI1 & 0.774 & \multirow{6}{*}{0.875} & \multirow{6}{*}{0.877} & \multirow{6}{*}{0.545} \\
\hline & EI2 & 0.720 & & & \\
\hline & EI3 & 0.733 & & & \\
\hline & EI4 & 0.674 & & & \\
\hline & EI5 & 0.841 & & & \\
\hline & EI6 & 0.675 & & & \\
\hline
\end{tabular}


Table 2 AVE Square Root and Correlation Matrix

\begin{tabular}{ccccc}
\hline Constructs & SCR & SCS & OC & EI \\
\hline SCR & $\mathbf{0 . 6 9 0}$ & & & \\
SCS & $0.443^{* *}$ & $\mathbf{0 . 6 8 3}$ & & \\
OC & $0.424 * *$ & $0.323^{* *}$ & $\mathbf{0 . 6 7 2}$ & \\
EI & $0.350^{* *}$ & $0.286^{* *}$ & $0.467 * *$ & $\mathbf{0 . 7 3 8}$ \\
\hline
\end{tabular}

Note: 1. Diagonal are AVE Square Root, the others are correlation coefficients.

2. ${ }^{*} \mathrm{p}<0.05, * * \mathrm{p}<0.01, * * * \mathrm{p}<0.001$.

\section{Hypotheses Testing}

This study used SEM to test all the hypotheses. The overall model fit, $\chi$ ${ }^{2}=335.035, \mathrm{GFI}=0.917, \mathrm{AGFI}=0.895, \mathrm{RMSEA}=0.049, \mathrm{RMR}=0.03$; the results showed that the overall model fit indices for the structural model were quite acceptable.

In the model, the standardized path coefficient of social capital in terms of information and resource accessibility to entrepreneurial intention was $0.15(\mathrm{p}<0.05)$, indicated a significant positive effect, supporting $\mathrm{H}_{1 \mathrm{a}}$. The standardized path coefficient of social capital in terms of career sponsorship on entrepreneurial intention was 0.07 , but did not reach the significant level, not supporting $\mathrm{H}_{1 b}$.

The standardized path coefficient of overconfidence on entrepreneurial intention was $0.44(\mathrm{p}<0.001)$, suggested a statistically significant and positive effect, supporting $\mathrm{H}_{2}$. The standardized path coefficient of social capital in terms of information and resource accessibility on an entrepreneur's overconfidence was 0.41 ( $<<0.001$ ), indicating a statistically significant and positive effect; $\mathrm{H}_{3 \mathrm{a}}$ was therefore supported. The standardized path coefficient of social capital in terms of career sponsorship on an entrepreneur's overconfidence was 0.19 ( $p<0.05), \mathrm{H}_{3 \mathrm{~b}}$ was also supported.

This study adopted the technique introduced by Sobel (1982) to confirm the mediating effect. The indirect effect should take into account of "independent variable $\rightarrow$ mediator variable $\rightarrow$ dependent variable" of which value of standardized path coefficient for both path should be multiplied. In accordance with Baron and Kenny (1986) based on Sobel (1982), indirect effect should be higher than direct effect to indicate the mediating effect in SEM. This study found that in the relationship of SCR $\rightarrow \mathrm{OC} \rightarrow \mathrm{EI}$, the indirect effect $=0.41 \times 0.44=0.1804$, the direct effect $=0.15$. The indirect effect was higher than direct effect, implying that overconfidence positively mediated the relationship between social capital in terms of information and resource accessibility and entrepreneurial intention, the mediation 
effect exist, supported $\mathrm{H}_{4 \mathrm{a}}$. The relationship of SCS $\rightarrow \mathrm{OC} \rightarrow \mathrm{EI}$, the indirect effect= $0.19 \times 0.44=0.0836$, the direct effect $=0.07$, the indirect effect was higher than direct effect, finding that overconfidence also positively mediated the relationship between social capital in terns of career sponsorship and entrepreneurial intention. $\mathrm{H}_{4 b}$ was supported.

\section{CONCLUSION}

The results of hypotheses testing are shown in Table 3.

Our empirical results showed that social capital in terms of information and resource accessibility has a positive effect on entrepreneurial intention of entrepreneurs, $\mathrm{so}_{\mathrm{la}}$ is supported. It means that if the entrepreneurs could obtain more resources and information to start the new business, they can accumulate the knowledge of business creation. The result concurs with the findings of Bhagvatula et al. (2010), Birley (1986), and Stam et al. (2014). Social capital in terms of career sponsorship otherwise has no significant positive effect on entrepreneurial intentions, so $\mathrm{H}_{1 \mathrm{~b}}$ is not supported. The reason behind the result could be due to our sampling targets; university students have no experience starting a business, and have no idea about the importance of social capital in terms of career sponsorship. This leads to the empirical results that social capital has no significant positive on entrepreneurial intention.

In addition, entrepreneur's overconfidence has a positive effect on entrepreneurial intention, so $\mathrm{H}_{2}$ is supported. The result concurs with the findings of Buttar (2015), and Hayward et al. (2010). Social capital in terms of information and resource accessibility (or in terms of and career sponsorship) has a positive impact on an entrepreneur's overconfidence, so $\mathrm{H}_{3 \mathrm{a}}$ and $\mathrm{H}_{3 \mathrm{~b}}$ are both supported. It indicates that the possession of social capital can impact the confidence level of an entrepreneur. Such findings were consistent with those of Baron (2008), Carr and Sequeira (2007), and Inkpen and Tsang (2005).

Finally, the study investigated the mediation effect of overconfidence between social capital and entrepreneurial intention. The results showed that social capital in terms of information and resource (or career sponsorship) has a positive impact on entrepreneurial intention via an entrepreneur's overconfidence, supporting $\mathrm{H}_{4 \mathrm{a}}$ and $\mathrm{H}_{4 \mathrm{~b}}$. The empirical results found that cognitive bias plays an important role in entrepreneurial opportunities, consistent with the findings of Mitchell et al. (2007) and Gigerenzer and Gaissmaier (2011). 
Table 3 Results of Hypotheses Testing

\begin{tabular}{|c|c|c|}
\hline Hypothesis & $\begin{array}{c}\text { Path } \\
\text { Coefficient }\end{array}$ & Results \\
\hline $\begin{array}{l}\mathrm{H}_{1 \mathrm{a}} \text { : Social capital in terms of information and resource } \\
\text { accessibility has a positive effect on entrepreneurial } \\
\text { intention. }\end{array}$ & $0.15^{* *}$ & Supported \\
\hline $\begin{array}{l}\mathrm{H}_{1 \mathrm{~b}} \text { : Social capital in terms of career sponsorship has a positive } \\
\text { effect on entrepreneurial intention. }\end{array}$ & 0.07 & $\begin{array}{l}\text { Not } \\
\text { Supported }\end{array}$ \\
\hline $\begin{array}{l}\mathrm{H}_{2} \text { : Entrepreneur's overconfidence has a positive effect on his } \\
\text { entrepreneurial intention. }\end{array}$ & $0.44 * * *$ & Supported \\
\hline $\begin{array}{l}\mathrm{H}_{3 \mathrm{a}} \text { : Social capital in terms of information and resource } \\
\text { accessibility has a positive effect on an entrepreneur's } \\
\text { overconfidence. }\end{array}$ & $0.41 * * *$ & Supported \\
\hline $\begin{array}{l}\mathrm{H}_{3 \mathrm{~b}} \text { : Social capital in terms of career sponsorship has a positive } \\
\text { effect on an entrepreneur's overconfidence. }\end{array}$ & $0.19^{* *}$ & Supported \\
\hline $\begin{array}{l}\mathrm{H}_{4 \mathrm{a}} \text { : Social capital in terms of information and resource } \\
\text { accessibility has a positive effect on entrepreneurial } \\
\text { intention of entrepreneurs, which is mediated by an } \\
\text { entrepreneur's overconfidence. }\end{array}$ & 0.1804 & Supported \\
\hline $\begin{array}{l}\mathrm{H}_{4 \mathrm{~b}} \text { : Social capital in terms of career sponsorship has a positive } \\
\text { effect on entrepreneurial intention of entrepreneurs, which } \\
\text { is mediated by an entrepreneur's overconfidence. }\end{array}$ & 0.0836 & Supported \\
\hline
\end{tabular}

\section{Managerial Implications}

Taiwan's central and local governments in Taiwan have carried out a series of entrepreneurship promotion policy initiatives to encourage young people to create new ventures. These policies started with good intentions, but if these policies were informed by a clearer understanding of who is most likely to choose an entrepreneurial career, then the initiatives would be more effective. Based on the results of this study, the following suggestions are made improve policies that encourage college and university graduates to choose entrepreneurial careers (Lewis, Harris, Morrison, and Ho, 2015).

First, a complex combination of factors is at play to induce individuals to choose entrepreneurship. Our findings can be used to inform graduate entrepreneurship encouragement policies by integrating individual (e.g., cognitive) and environmental (e.g., social capital properties) factors into criteria for the selection and evaluation of young people who are likely to careers as entrepreneurs. 
Second, before implementing the entrepreneurship encouragement policy, it would be wise to identify who is most likely to develop entrepreneurial intentions by testing of the characteristics of their social network. These tests may save money and improve policy efficiency.

Finally, the findings of this study suggest that overconfidence has a significant and positive effect on entrepreneurial intention; the more overconfident someone is, the more likely that person is to have entrepreneurial intention. Entrepreneurial overconfidence makes people less fearful of difficulties when creating a new business. Entrepreneurial training programs should increase entrepreneurial intention by encouraging students to be more confident.

\section{Limitations and Future Research}

There are some limitations in this study. One is that the samples of this study were university students. It is suggested that the target respondents be expanded to the people with a different background. Moreover, future research could investigate various types of cognitive bias and social capital to investigate if they have different effects on entrepreneurial intention. It may consider different types of cognitive biases (e.g., illusion of control and representativeness) and compare their mechanisms.

\section{REFERENCES}

Adler, P. S., \& Kwon, S.W. (2002). Social capital: Prospects for a new concept. Academy of Management Review, 27(1), 17-40. http://dx.doi.org/10.2307/4134367

Baron, R. A. (2008). The role of affect in the entrepreneurial process. Academy of Management Review, 33(2), 328-340. http://dx.doi.org/10.5465/AMR.2008.31193166

Baron, R. A., \& Ensley, M. (2006). Opportunity recognition as the detection of meaningful patterns: Evidence from comparisons of novice and experienced entrepreneurs. Management Science, 52(9), 1331-1344. http://dx.doi.org/10.1287/mnsc.1060.0538

Baron, R. A. (1998). Cognitive mechanisms in entrepreneurship: Why and when entrepreneurs think differently than other people. Journal of Business Venturing, 13(4), 275-294. http://dx.doi.org/10.1016/S0883-9026(97)00031-1

Baron, R. A., \& Tang, J. (2009). Entrepreneurs' social skills and new venture performance: Mediating mechanisms and cultural generality. Journal of Management, 35(2), 282-306. http://dx.doi.org/10.1177/0149206307312513

Baron, R. M., \& Kenny, D. A. (1986). The moderator-mediator variable distinction in social psychological research: Conceptual, strategic, and statistical considerations. 
Journal of personality and social psychology, 51(6), 1173. http://dx.doi.org/10.1037/0022-3514.51.6.1173

Bhagvatula, S., Elfring, T., Van Tilburg, A., \& Van De Bunt, G. G. (2010). How social and human capital influence opportunity recognition and resource mobilization in India's handloom industry. Journal of Business Venturing, 25(3), 245-260. http://dx.doi.org/10.1016/j.jbusvent.2008.10.006

Bird, B. (1988). Implementing entrepreneurial ideas: The case for intention. Academy of Management Review, 13(3), 442-453. http://dx.doi.org/10.5465/AMR.1988.4306970

Birley, S. (1986). The role of networks in the entrepreneurial process. Journal of Business Venturing, 1(1), 107-117 http://dx.doi.org/10.1016/0883-9026(85)90010-2

Brüderl, J., \& Preisendörfer, P. (1998). Network support and the success of newly founded business. Small Business Economics, 10(3), 213-225. https://doi.org/10.1023/A:1007997102930

Burt, R. S. (1995). Structural holes: The social structure of competition. Boston, MA: Harvard University Press.

Busenitz, L. W., \& Barney, J. B. (1997). Differences between entrepreneurs and managers in large organizations: Biases and heuristics in strategic decision making. Journal of Business Venturing, 12(1), 9-30. http://dx.doi.org/10.1016/S0883-9026(96)00003-1

Buttar, H. M. (2015). Formation of entrepreneurial career intentions: The role of sociocognitive factors. Journal of Employment Counseling, 52(1), 2-17. http://dx.doi.org/10.1002/j.2161-1920.2015.00052.x

Carr, J. C., \& Sequeira, J. M. (2007). Prior family business exposure as intergenerational influence and entrepreneurial intent: A theory of planned behavior approach, Journal of Business Research, 60(10), 1090-1098. http://dx.doi.org/10.1016/j.jbusres.2006.12.016

Chao, G. T. (1997). Mentoring phases and outcomes. Journal of Vocational Behavior, 51(1), 15-28. http://dx.doi.org/10.1006/jvbe.1997.1591

Chin, W. (1998). Issues and opinion on structural equation modeling. MIS Quarterly, 22(1), 7-16.

Corbett, A. C. (2007). Learning asymmetries and the discovery of entrepreneurial opportunities. Journal of Business Venturing, 22(1), 97-118. http://dx.doi.org/10.1016/j.jbusvent.2005.10.001

Das, T. K., \& Teng, B. S. (1997). Time and entrepreneurial risk behavior. Entrepreneurship theory and practice, 22(2), 69-71. 
De Carolis, D. M., \& Saparito, P. (2006). Social capital, cognition and entrepreneurial opportunities: A theoretical framework. Entrepreneurship Theory and Practice, 30(1), 41-56. http://dx.doi.org/10.1111/j.1540-6520.2006.00109.x

De Carolis, D. M., Yang, Y., Deeds, D. L., \& Nelling, E. (2009). Weathering the storm: The benefit of resources to high-technology ventures navigating adverse events. Strategic Entrepreneurship Journal, 3(2), 147-160. http://dx.doi.org/10.1002/sej.68

Dolfsma, W., \& Dannreuther, C. (2003). Subjects and boundaries: Contesting social capital-based policies. Journal of Economic Issues, 37(2), 405-413. http://dx.doi.org/10.1080/00213624.2003.11506588

Fisher, C. D. (1985). Social support and adjustment to work: A longitudinal study. Journal of Management, 39-53. http://dx.doi.org/10.1177/014920638501100304

Foley, M. W., \& Edwards, B. (1997). Editors' introduction escape from politics? Social theory and the social capital debate. American Behavioral Scientist, 40(5), 550-561.

Fornell, C., \& Larcker, D. F. (1981). Evaluating structural equation models with unobservable variables and measurement error. Journal of Marketing Research, 39-50. http://dx.doi.org/10.2307/3151312

Franke, N., Von Hippel, E., \& Schreier, M. (2006). Finding commercially attractive user innovations: A test of lead-user theory. Journal of Product Innovation Management, 23(4), 301-315. http://dx.doi.org/10.2139/ssrn.721182

Gigerenzer, G., \& Gaissmaier W. (2011). Heuristic decision making. Annual Review of Psychology, 62, 451-482. http://dx.doi.org/10.1146/annurev-psych-120709-145346

Hair, J., Black, W., Babin, B., Anderson, R., \& Tatham, R. (2006). Multivariate data analysis. Uppersaddle River, N.J.: Pearson Prentice Hall.

Hatten, T. S., \& Coulter, M. K. (1997). Small business: Entrepreneurship and beyond. Uppersaddle River, N.J.: Pearson Prentice Hall.

Hayward, M. L., Forster, W. R., Sarasvathy, S. D., \& Fredrickson, B. L. (2010). Beyond hubris: How highly confident entrepreneurs rebound to venture again. Journal of Business Venturing, 25(6), 569-578. http://dx.doi.org/10.1016/j.jbusvent.2009.03.002

Hayward, M. W., O’Brien, J., Hofmeyr, M., \& Kerley, G. I. H. (2006). Prey preferences of the African wild dog Lycaon pictus (Canidae Carmivora): Ecological requirements for their conservation. Journal of Mammalogy, 87(6), 1122-1131. https://doi.org/10.1644/05-MAMM-A-304R2.1 
Inkpen, A. C. \& Tsang, E. W. K. (2005). Social capital, networks, and knowledge transfer. Academy of Management Review, 30(1), 146-165. http://dx.doi.org/10.5465/AMR.2005.15281445

Ireland, R. D., Hitt, M. A., \& Sirmon, D. G. (2003). A model of strategic entrepreneurship: The construct and its dimensions. Journal of management, 29(6), 963-989. http://dx.doi.org/10.1016/S0149-2063_03_00086-2

Kannadhasan, M., \& Nandagopal, R. (2010). Influence of decision makers' characteristics on risk analysis in strategic investment decisions. Journal of Modern Accounting and Auditing, 6(4), 38.

Keh, H., Foo, M., \& Lim, B. (2002). Opportunity evaluation under risky conditions: The cognitive processes of entrepreneurs. Entrepreneurship Theory and Practice, 27(2), 125-148. http://dx.doi.org/10.1111/1540-8520.00003

Koellinger, P., Minniti, M., \& Schade, C. (2007). "I think I can, I think I can": Overconfidence and entrepreneurial behavior. Journal of Economic Psychology, 28(4), 502-527. http://dx.doi.org/10.1016/j.joep.2006.11.002

Krueger, N. F. (2005). Sustainable entrepreneurship: Broadening the definition of "opportunity". Entrepreneurship in a Diverse World, 7, 2005.

Krueger, N. F., Reilly, M. D., \& Carsrud, A. L. (2000). Competing models of entrepreneurial intentions. Journal of Business Venturing, 15(5), 411-432. http://dx.doi.org/10.1016/S0883-9026(98)00033-0

Laibson, D., \& Zeckhauser, R. (1998). Amos Tversky and the ascent of behavioral economics. Journal of Risk and Uncertainty, 16(1), 7-47. https://doi.org/10.1023/A:1007717224343

Lewis, K. V., Harris, C., Morrison, R., \& Ho, M. (2015), The entrepreneurship-motherhood nexus. Career Development International, 20(1), 21-37. http://dx.doi.org/10.1108/CDI-07-2014-0090

Liao, J. \& Welsch, H. (2005). Roles of social capital in venture creation: Key dimensions and research implications. Journal of Small Business Management, 43(4), 345-362. http://dx.doi.org/10.1111/j.1540-627X.2005.00141.x

Liñán, F., \& Santos, F. J. (2007). Does social capital affect entrepreneurial intentions? International Advances in Economic Research, 13(4), 443-453. https://doi.org/10.1007/s11294-007-9109-8

McGee, J. E., Peterson, M., Mueller, S. L., \& Sequeira, J. M. (2009). Entrepreneurial self-efficacy: Refining the measure. Entrepreneurship Theory and Practice, 33(4), 965-988. http://dx.doi.org/10.1111/j.1540-6520.2009.00304.x

Mitchell, R. K., Busenitz, L. W., Bird, B., Marie Gaglio, C., McMullen, J. S., Morse, E. A., \& Smith, J. B. (2007). The central question in entrepreneurial cognition 
research 2007. Entrepreneurship Theory and Practice, 31(1), 1-27. http://dx.doi.org/10.1111/j.1540-6520.2007.00161.x

Moore, D. A., \& Healy, P. J. (2008). The trouble with overconfidence. Psychological Review, 115(2), 502-517. http://dx.doi.org/10.1037/0033-295X.115.2.502

Moore, D. A., \& Kim, T. G. (2003). Myopic social prediction and the solo comparison effect. Journal of Personality and Social Psychology, 85(6), 1121. http://dx.doi.org/10.1037/0022-3514.85.6.1121

Murphy, P. J. (2011). A $2 \times 2$ conceptual foundation for entrepreneurial discovery theory. Entrepreneurship Theory and Practice, 35(2), 359-374. http://dx.doi.org/10.1111/j.1540-6520.2010.00368.x

Nahapiet, J., \& Ghoshal, S. (1998). Social capital, intellectual capital, and the organizational advantage. Academy of Management Review, 23(2), 242-266. http://dx.doi.org/10.5465/AMR.1998.533225

Payne, G. T., Moore, C. B., Griffis, S. E., \& Autry, C. W. (2011). Multilevel challenges and opportunities in social capital research. Journal of Management, 37(2), 491-520. http://dx.doi.org/10.1177/0149206310372413

Van Praag, C. M., \& Versloot, P. H. (2007). What is the value of entrepreneurship? : A review of recent research. Small Business Economics, 29(4), 351-382. http://dx.doi.org/10.1007/s11187-007-9074-x

Sánchez, J. C., Carballo, T., \& Gutiérrez, A. (2011). The entrepreneur from a cognitive approach. Psicothema, 23(3), 433-438.

Schlaegel, C., \& Koenig, M. (2014). Determinants of entrepreneurial intent: A meta-analytic test and integration of competing models. Entrepreneurship Theory and Practice, 38(2), 291-332. http://dx.doi.org/10.1111/etap.12087

Seibert, S. E., Kraimer, M. L., \& Liden, R. C. (2001). A social capital \& theory of career success. Academy of Management Journal, 44(2), 219-237. http://dx.doi.org/10.2307/3069452

Sequeira, J., Mueller, S. L., \& McGee, J. E. (2007). The influence of social ties and self-efficacy in forming entrepreneurial intentions and motivating nascent behavior. Journal of Developmental Entrepreneurship, 12(03), 275-293. http://dx.doi.org/10.1142/S108494670700068X

Shane, S. A., \& Venkataraman, S. (2000). The promise of entrepreneurship as a field of research. Academy of Management Review, 25(1), 217-226. http://dx.doi.org/10.5465/AMR.2000.2791611

Shaver, K. G., \& Scott, L. R. (1991). Person, process and choices: The philosophy of new venture creation. Entrepreneurship Theory and Practice, 16(2), 23-45.

Simon, M., Houghton, S. M., \& Aquino, K. (2000). Cognitive biases, risk perception, 
and venture formation: How individuals decide to start companies. Journal of business venturing,15(2), 113-134. http://dx.doi.org/10.1016/S0883-9026(98)00003-2 Sobel, M. E. (1982). Asymptotic confidence intervals for indirect effects in structural equation models. Sociological Methodology, 13, 290-312. http://dx.doi.org/10.2307/270723

Stam, W., Arzlanian, S., \& Elfring, T. (2014). Social capital of entrepreneurs and small firm performance: A meta-analysis of contextual and methodological moderators. Journal of Business Venturing, 29(1), 152-173. http://dx.doi.org/10.1016/j.jbusvent.2013.01.002

Sullivan, R. (2000). Entrepreneurial learning and mentoring. International Journal of Entrepreneurial Behaviour \& Research, 6(3), 160-175. http://dx.doi.org/10.1108/13552550010346587

Tominc, P., \& Rebernik, M. (2007). Growth aspirations and cultural support for entrepreneurship: A comparison of post-socialist countries. Small Business Economics, 28 (2), 239-255. http://dx.doi.org/10.1007/s11187-006-9018-x

Townsend, D. M., Busenitz, L. W., \& Arthurs, J. D. (2010). To start or not to start: Outcome and ability expectations in the decision to start a new venture. Journal of Business Venturing, 25(2), 192-202. http://dx.doi.org/10.1016/j.jbusvent.2008.05.003

Trevelyan, R. (2008). Optimism, overconfidence and entrepreneurial activity. Management Decision, 46(7), 986-1001. http://dx.doi.org/10.1108/00251740810890177

Tubbs, M. E., \& Ekeberg, S. E. (1991). The role of intentions in work motivation: Implications for goal-setting theory and research. Academy of Management Review, 16(1), 180-199. http://dx.doi.org/10.2307/258611

Wadeson, N. (2008). Entrepreneurial strategy: Sequential investment and information gathering. in M. Terziovski (Ed.) Energizing management through innovation and entrepreneurship: European research and practice, NY: Routledge.

York, J. G., \& Venkataraman, S. (2010). The entrepreneur-environment nexus: Uncertainty, innovation, and allocation. Journal of Business Venturing, 25(5), 449-463. http://dx.doi.org/10.1016/j.jbusvent.2009.07.007

Zacharakis, A., \& Shepherd, D. (2001). The nature of information and overconfidence on venture capitalists' decision making. Journal of Business Venturing, 16(4), 311-332. http://dx.doi.org/10.1016/S0883-9026(99)00052-X

Zimmerman, M., \& Zeitz, G. (2002). Beyond survival: Achieving new venture growth by building legitimacy. Academy of Management Review, 27(3), 414-431. http://dx.doi.org/10.5465/AMR.2002.7389921 


\section{Appendix Measurement Scales and Items}

\begin{tabular}{|c|c|}
\hline & Social capital \\
\hline 1 & I can get resource to reach my new ideas and goals. \\
\hline 2 & $\begin{array}{l}\text { When I need additional resource and information, I can usually get the resources to } \\
\text { achieve my goals. }\end{array}$ \\
\hline 3 & When I need to get the job well done, I can get the resource and information easily. \\
\hline 4 & $\begin{array}{l}\text { When I need to complete the job, I can easily obtain the necessary and important } \\
\text { information. }\end{array}$ \\
\hline 5 & I always get the information which is useful for me \\
\hline 6 & My friends or family members will help me to complete an emergency or difficult work. \\
\hline 7 & When I'm with friends or family to discuss my feelings, they can share their feelings. \\
\hline 8 & $\begin{array}{l}\text { My friends and family will encourage me when I encounter the anxiety and fear things at } \\
\text { work. }\end{array}$ \\
\hline 9 & $\begin{array}{l}\text { When I encounter difficulties my friends or family will offer their personal } \\
\text { experiences. }\end{array}$ \\
\hline 10 & $\begin{array}{l}\text { I will discuss my feeling about the progresses and relationship on my work or family } \\
\text { conflict with my friends and family members. }\end{array}$ \\
\hline
\end{tabular}

1 How much confidence do you have in your ability to design a product or service that will satisfy customer needs and wants?

2 How much confidence do you have in your ability to determine a competitive price for a new product or service?

3 How much confidence do you have in your network--- i.e. make contact with and exchange information with others?

4 How much confidence do you have in your ability to recruit and hire employees?

5 How much confidence do you have in your ability to manage financial assets of your business?

\section{Entrepreneurial Intention}

1 I intend to set up a company in the future.

2 I never search for business start-up opportunities.

3 I save money to start a business.

4 I do not read books on how to set up a firm.

5 I have no plans to start up my own business.

6 I spend time learning about starting a firm. 
